\title{
Transcomplejidad: Imaginarios y Realidades Investigativas
}

\author{
PhD. Olga Carolina Molano Lucena \\ Universidad Nacional Experimental Libertador, UPEL-IPB \\ olgacmolano@gmail.com \\ Lara, Venezuela
}

\section{Editorial}

La realidad investigativa, tiene configuraciones empíricas y epistémicas resultantes de las múltiples maneras de ser percibida, interpretada, comprendida o medida. Existen tantas verdades como personas en el mundo; algunas concepciones son compartidas por una comunidad, otras rechazadas. Sin embargo, en el recorrido filosófico del conocimiento hacia la transcomplejidad, emergen imaginarios colectivos que reproducen paradigmas que alteran las condiciones ontológicas, axiológicas y teleológicas, entre otras; desde las perspectivas valorativas de los fenómenos estudiados.

La necesidad de trascender los límites epocales, disciplinarios y paradigmáticos, llevan a reflexionar acerca de la praxis investigativa de educación, en la cual coexisten (a) una realidad objetiva que es percibida de manera subjetiva, (b) el saber experiencial ante el conocimiento formal, (c) la dialógica desde una conciencia mesurable de una lógica que debe atender a las perspectivas ideográficas propias de la cultura y valores socioeducativos en un mundo global; para señalar algunas inquietudes, que exigen al investigador social a ir más allá, para plantear la duda razonable de ¿si estamos transitando los escenarios de la transcomplejidad?

Los artículos científicos presentados en el Instituto Internacional de Investigación y Desarrollo Tecnológico Educativo INDTEC, por ejemplo, representan producciones intelectuales generadas por investigaciones desde diversas configuraciones epistémicas y metodológicas; e inclusive algunas tienen abordajes transdiciplinarios. Schavino y Villegas (2010): explican que 
se "inspira en la multidimensionalidad de saberes, la pluralidad y la interacción que emergen desde el trabajo en equipo y el encuentro transdisciplinario" (pág. 5). Este reconocimiento de la existencia de lo cotidiano y de lo imaginario en la realidad educativa, abre las posibilidades a una interconexión migratoria de saberes, sin pretender desplazar unos por otros.

Los señalamientos anteriores, hacen indispensable abordar la dimensión etimológica de la transcomplejidad, como complexus-us, vocablo latino, cuyo significado es "abrazo"; y cum como preposición del ablativo "con y plexus-us", ambas conjunciones dan la idea de un tejido o entrelazado. Es decir, su prefijo trans, en el Diccionario de la Real Académica Española (DRAE, 2017, pág. 1), define la idea de movimiento tránsito, metamorfosis y fusión, que transfigure, transmute, así como transverse la realidad objetiva a la subjetiva y viceversa.

Por ende, la transcomplejidad es una integración del pensamiento complejo con la transdisciplinariedad de las ciencias. Como antecedente de las propuestas de Morín (1990, pág. 101), enfatiza una doble lógica para comprender dos nociones antagónicas, como son el orden y el desorden, las cuales dan origen a la organización como un modo de pensar, en el que se intenta asumir el desafío de la incertidumbre y la contradicción para abordar un cambio paradigmático.

Desde una visión relativista la transcomplejidad, según Gómez y Jiménez (2002, pág. 44), asume los principios del conocimiento desde una perspectiva complementaria para convertir la organización, el religue, la contextualización y la globalización para confrontar el pensamiento clásico. Asimismo, Moreno (2002, pág. 118), explica que no sólo sirve para entender la complejidad de la naturaleza humana; sino que especialmente, se diferencia de otras perspectivas porque se concentra en la complejidad social, con un mayor grado de incertidumbre presente en la realidad educativa desde una interacción entre varias disciplinas. 
El concepto de transdisciplinariedad nació en la década de los 70; y es Morín, quién en los años 80 , expone el término transdisciplinar, partiendo de concepto y análisis que provienen de diferentes disciplinas, las cuales se integran para captar características inadvertidas desde otras ópticas. Igualmente, Sotolongo (2007): señala que va más allá de una visión multidisciplinaria, puesto que se enfoca en "el respeto a la pluralidad de saberes" (págs. 6-20). Por tanto, reconocer la existencia de múltiples niveles de realidad, debido a la complejidad e incertidumbre que envuelven los contextos socioeducativos.

La perspectiva integradora interdisciplinaria, de acuerdo con Morín en el 2002, citado por Balza (2010): permite la "construcción del conocimiento de la realidad, que no es simple, ni es compleja" (pág. 93); de ahí que debe existir una eficiente interacción y autoorganización de varias disciplinas; y para ello, debe surgir una nueva epistemología, con una visión estratégica transversal, flexible, abierta, complementaria e integradora para buscar la solución de problemas complejos concretos en la realidad social.

La transdisciplinariedad según Ugas (2016): "se refiere a la transferencia o intercambio de teoría, métodos de una disciplina a otra. Igualmente alude a la reunión de expertos para realizar un diagnóstico" (pág. 66). Como lo plantea este autor, existen tres tipos que responden a los niveles de (a) aplicación, (b) epistemológico y (c) concepción de nuevas disciplinas. Todas, conducen al análisis de las interrelaciones de los fenómenos emergentes en los procesos investigativos que generan nuevos conocimientos de la realidad y de los imaginarios socioeducativos.

En este sentido, Delgado (2011, pág. 136), manifiesta qué se trata de un diálogo de saberes disciplinarios no lineales para la construcción conjunta de problemas de investigación y para la búsqueda de soluciones posibles. de ahí que exista una relación entre la complejidad y la transdisciplinariedad en el entorno educativo puesto que las disciplinas contribuyen en la educación a 
articular los conocimientos para dar respuesta a las concepciones antropológicas, psicológicas, sociológicas, pedagógicas, entre otras, que conforman el currículo de todos los niveles del sistema educativo.

En el contexto sociales, los imaginarios en las realidades transcomplejas en la investigación educativa benefician a las comunidades del conocimiento agrupadas en las líneas de investigación de las diversas universidades, así como también a los ámbitos socioeducativos que están en una permanente búsqueda de soluciones a las problemáticas que los aquejan; además abren en un mundo globalizado, las posibilidades de información, comunicación y promoción del conocimiento pertinente ante los cambios epocales.

Resumiendo los aspectos tratados en esta disertación acerca de la transcomplejidad, se puede configurar la transdisciplinariedad como el tejido cognoscitivo, desde el cual se entrelazan de manera complementaria a la interacción multidimensional de saberes, con una apertura paradigmática plural a partir de los intercambios disciplinarios, cuyo interés investigativo se fundamenta en la dinámica de la acción transformadora, apoyada en la existencia de la percepción de distintos niveles de realidad, desde la cual surgen nuevas lógicas emergentes de la complejidad socioeducativa.

La revisión de los aspectos epistémicos y las concepciones teóricas que preceden, permite concluir que los avances sociales, pedagógicos, científicos y tecnológicos, entre otros en los ámbitos educativos; han generado una crisis en los paradigmas de investigación, debido a la complejidad e incertidumbre que impregnan las realidades socioeducativas, ocasionando una reflexión profunda desde la cual se vuelve la mirada holística, interdisciplinaria desde múltiples manifestaciones de los fenómenos emergentes para asumir el reto de ampliar, dinamizar, complementar los saberes en las comunidades del conocimiento.

Finalmente, el salto cuántico del pensamiento simplista al complejo, 
abre el camino a la integración disciplinar, de tal modo que la transcomplejidad va más allá de los imaginarios de la realidad social en la contextualización de las fenómenos emergentes. Valdría la pena preguntarse, ante la parálisis paradigmática ¿qué oportunidades investigativas estaríamos perdiendo?, si no orientamos la mirada a la complementariedad, sinergia, integralidad y reflexividad propias de la postmodernidad.

Palabras clave: conocimiento; investigación; educación. 


\section{Transcomplejity: Imaginaries and Investigative Realities}

\section{Editorial}

The investigative reality has empirical and epistemic configurations resulting from the multiple ways of being perceived, interpreted, understood or measured. There are as many truths as there are people in the world; Some conceptions are shared by a community, others rejected. However, in the philosophical journey of knowledge towards transcomplexity, collective imaginaries emerge that reproduce paradigms that alter the ontological, axiological and teleological conditions, among others; from the evaluative perspectives of the phenomena studied.

The need to transcend the epochal, disciplinary and paradigmatic limits, leads to reflect on the research praxis of education, in which (a) an objective reality that is perceived in a subjective way coexist, (b) experiential knowledge before formal knowledge, (c) the dialogic from a measurable conscience of a logic that must attend to the ideographic perspectives of the socio-educational culture and values in a global world; to point out some concerns, which require the social researcher to go further, to raise the reasonable doubt of whether we are transiting the scenarios of transcomplexity?

The scientific articles presented at the Instituto Internacional de Investigación y Desarrollo Tecnológico Educativo INDTEC, for example, represent intellectual productions generated by research from diverse epistemic and methodological configurations; and even some have transdisciplinary approaches. Schavino and Villegas (2010): explain that "it is inspired by the multidimensionality of knowledge, plurality and interaction that emerge from teamwork and transdisciplinary meeting" (p.5). This recognition of the existence of the everyday and the imaginary in the educational reality, opens the possibilities to a migratory interconnection of knowledge, without trying to displace one for another. 
The previous statements make it indispensable to address the etymological dimension of transcomplexity, as complexus-us, Latin word, whose meaning is "embrace"; and cum as a preposition of the ablative "with and plexus-us", both conjunctions give the idea of a fabric or interlacing. That is, its prefix trans, in the Dictionary of the Royal Spanish Academic (DRAE, 2017, p.1), defines the idea of movement, metamorphosis and fusion, which transfigure, transmute, as well as transfer objective to subjective reality and vice versa.

Therefore, transcomplexity is an integration of complex thinking with the transdisciplinarity of sciences. As antecedent of the proposals of Morín (1990, p.101), he emphasizes a double logic to understand two antagonistic notions, such as order and disorder, which give rise to the organization as a way of thinking, in which try to take on the challenge of uncertainty and contradiction to address a paradigm shift.

From a relativist view, transcomplexity, according to Gómez and Jiménez (2002, p.44), assumes the principles of knowledge from a complementary perspective to convert the organization, religion, contextualization and globalization to confront classical thought. Likewise, Moreno (2002, p.118), explains that it not only serves to understand the complexity of human nature; but especially, it differs from other perspectives because it focuses on social complexity, with a greater degree of uncertainty present in the educational reality from an interaction between several disciplines.

The concept of transdisciplinarity was born in the 70s; and it is Morín, who in the 80s, exposes the transdisciplinary term, starting from concept and analysis that come from different disciplines, which are integrated to capture inadvertent characteristics from other perspectives. Likewise, Sotolongo (2007): points out that it goes beyond a multidisciplinary vision, since it focuses on "respect for the plurality of knowledge" (pp.6-20). Therefore, recognize the 
existence of multiple levels of reality, due to the complexity and uncertainty that surround the socio-educational contexts.

The interdisciplinary integrative perspective, according to Morín in 2002, cited by Balza (2010): allows the "construction of knowledge of reality, which is neither simple nor complex" (p.93); hence, there must be an efficient interaction and self-organization of several disciplines; and for that, a new epistemology must emerge, with a transversal, flexible, open, complementary and integrating strategic vision to seek the solution of concrete complex problems in the social reality.

The transdisciplinarity according to Ugas (2016): "refers to the transfer or exchange of theory, methods from one discipline to another. It also refers to the meeting of experts to make a diagnosis "(p.66). As this author suggests, there are three types that respond to the levels of (a) application, (b) epistemological and (c) conception of new disciplines. All of them lead to the analysis of the interrelationships of the emergent phenomena in the research processes that generate new knowledge of reality and socio-educational imaginaries.

In this sense, Delgado (2011, p.136), states that it is a dialogue of nonlinear disciplinary knowledge for the joint construction of research problems and for the search for possible solutions. Hence, there is a relationship between complexity and transdisciplinarity in the educational environment since the disciplines contribute in education to articulate knowledge to respond to the anthropological, psychological, sociological, pedagogical conceptions, among others, that make up the curriculum of all levels of the education system.

In the social context, the imaginaries in the transcomplex realities in educational research benefit the knowledge communities grouped in the research lines of the various universities, as well as the socio-educational areas that are constantly searching for solutions to the problems that afflict them; they also open in a globalized world, the possibilities of information, 
communication and promotion of relevant knowledge in the face of epochal changes.

Summarizing the aspects dealt with in this dissertation about transcomplexity, transdisciplinarity can be configured as the cognitive tissue, from which they are intertwined in a complementary way to the multidimensional interaction of knowledge, with a plural paradigmatic opening from the disciplinary exchanges, whose Investigative interest is based on the dynamics of transformative action, supported by the existence of the perception of different levels of reality, from which new emerging logics of socioeducational complexity emerge.

The revision of the epistemic aspects and the theoretical conceptions that precede, allows to conclude that the social, pedagogical, scientific and technological advances, among others in the educational fields; they have generated a crisis in the research paradigms, due to the complexity and uncertainty that permeate the socio-educational realities, causing a deep reflection from which the holistic, interdisciplinary view becomes from multiple manifestations of the emerging phenomena to assume the challenge of expanding, energize, complement the knowledge in the knowledge communities.

Finally, the quantum leap from simplistic thinking to complex opens the way to disciplinary integration, in such a way that transcomplexity goes beyond the imaginaries of social reality in the contextualization of emerging phenomena. It would be worth asking, in the face of paradigmatic paralysis, what investigative opportunities would we be losing?, if we do not focus on the complementarity, synergy, integrality and reflexivity of postmodernity.

Keywords: knowledge; research; education.

Date Received: 04-06-2018

Date Acceptance: 16-07-2018 


\section{Referencias}

Balza, A. (2010). Educación, investigación y aprendizaje. Una hermeneusis desde el pensamiento complejo y transdisciplinario.

En Wilinski, A., Méndez, M., \& Martínez, I. La Complejidad como una opción para la construcción de saberes en la investigación doctoral. Revista de Pedagogía, 34-35(95-96), 89-109. Caracas, Venezuela: Universidad Central de Venezuela. Recuperado de: http://www.redalyc.org/pdf/659/65932613007.pdf

Delgado, C. (2011). Transdisciplina, Curricular Universitaria e Investigación. En García, J. Betancourt, J. \& Martínez, F. La Transdisciplina y el Desarrollo humano, págs. 134-153. México: Universidad Autónoma Metropolitana.

DRAE (2017). Realidad. Diccionario de la Real Academia Española. 23a Edición. Madrid, España: Asociación de Academias de la Lengua Española. Recuperado de:

http://buscon.rae.es/drael/SrvltConsulta?TIPO BUS=3\&LEMA=realida $\underline{\mathrm{d}}$

Gómez, R., \& Jiménez, J. (2002). De los Principios del Pensamiento Complejo. En Velilla, M. Manual de iniciación pedagógica al Pensamiento Complejo, págs. 24-35. Bogotá: ICFES-UNESCO.

Moreno, J. (2002). Tres Teorías que Dieron Origen al Pensamiento Complejo: Sistémica, Cibernética e Información. En Velilla, M. Manual de iniciación pedagógica al pensamiento complejo, págs. 116120. Bogotá: ICFES-UNESCO.

Morín, E. (1990). Introducción al Pensamiento Complejo. España: Gedisa Editorial.

Schavino, N., \& Villegas, C. (2010). De la Teoría a la Praxis en el Enfoque Integrador Transcomplejo. Buenos Aires, Argentina: Congreso Iberoamericano de Educación. 
Sotolongo, P. (2007). Complejidad, no Linealidad y Redes Distributivas.

Complexus, Revista sobre Complejidad, Ciencia y Estética, 3(1), 1-108, ISSN: 0718-1515. Recuperado de:

http://sintesys.cl/assets/complexus7.pdf\#page $=7$

Ugas, G. (2016). Epistemología. Un Territorio Discursivo Co-Disciplinario. San Cristóbal, Venezuela: Ediciones del Taller Permanente de Estudios Epistemológicos en Ciencias Sociales. 


\section{PhD. Olga Carolina Molano Lucena}

e-mail: olgacmolano@gmail.com

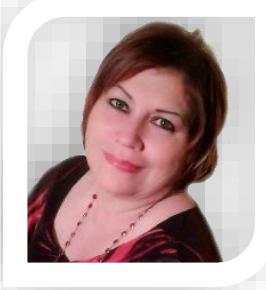

Nacida en Venezuela. Licenciada en Educación, Universidad Nacional Experimental Simón Rodríguez (UNESR). Maestría en Planificación Educativa, Universidad Rafael Urdaneta (URU). Doctorado en Educación Universidad Nacional Experimental Libertador - Instituto Pedagógico de Barquisimeto (UPEL-IPB). Postdoctorado en Estudios Libres: La Epistemología desde su

Praxis y Productividad, Universidad Fermín Toro (UFT). Experta en E-learning (FATLA). Docente, tutora y jurado de pregrado, postgrado. Investigadora del programa de Promoción del Estímulo a la Investigación e Innovación del Ministerio de Ciencia y Tecnología (PEII-ONCTI); Adscrita al Centro de Investigación Contextos y Praxis Socio Educativa (CICPSE UPEL-IPB). Diseñadora de los Proyectos socioeducativos "Cascada y LUCES". Conferencista, escritora de artículos y libros. 